\title{
Factor Analysis of Postpartum Blues on Post Partum Patients at Puskesmas Proppo Pamekasan
}

\author{
Hilmah Noviandry Rahman ${ }^{1}$, \\ Byba Melda Suhita ${ }^{2}$ \\ ${ }^{1}$ Magister of Health Study \\ Program of STIKes Surya Mitra \\ Husada Kediri \\ ${ }^{2}$ Lecturer of Stikes Surya Mitra \\ Husada Kediri \\ Email: \\ ilma_ribi@yahoo.com
}

Received : October 4, 2018

Accepted : October 6, 2018

Published : November 30, 2018

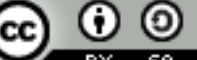

This is an open-acces article distributed under the terms of the Creative Commons Attribution-ShareAlike 4.0 International License.

\section{INTRODUCTION}

Childbirth is a great gift for women and a very happy moment, but sometimes there are women who experience sadness and moodiness after childbirth. Post partum blues (PPB) or maternity blues or baby blues are mothers who experience sadness or moodiness after childbirth, caused by hormonal changes in a woman's body during pregnancy, as well as feelings of sadness associated with her baby after childbirth. It is marked as an unexplained anxiety symptom, crying for no reason, impatient, insecure, irritable, feels less like a baby. (Marmi, 2012). This PPB usually appears on the second day to two weeks, the ESD is experienced up to $50-80 \%$ of new mothers. The incidence of 
PPH incidence overseas is quite high reach $26-85 \%$, globally estimated $20 \%$ of women give birth to MARPs. In the dutch of 2001 estimated 2-10\% of mothers gave birth to this disorder (Anggraini, 2010).

A study conducted in Sweden, Australia, Italy and Indonesia using EPDS (Edingburg baby blues syndrome Postnatal Depression Scale) in 1993 showed that $73 \%$ of women had PPB. In 2008, almost $70 \%$ of new mothers suffered from PPB. Meanwhile in 2009 in Indonesia today there are almost $80 \%$ of mothers experience it at post-maternity and $75 \%$ of them occur in primigravida mother (Rahmi, 2013). While research in Singapore in 2010 got the number of post partum blues about $10 \%$ $20 \%$. According to Ade (2011) in Indonesia the incidence of post partum blues between $50-70 \%$ of women postpartum. At Puskesmas Proppo of Pamekasan District through the temporary data collected by researchers using EPDS (Edingburg baby blues syndrome Postnatal Depression Scale) it is known that during January to August of 2017 there were 56 mothers who experienced post partum blues of Total of 373 mothers giving birth or 15\% of total birth (Puskesmas Proppo data, 2017).

The cause of post partum blues can be more than one cause so that the symptoms and signs of post partum blues is actually a multifactorial mechanism. Knowledge is the result of knowing and occurs after sensing an object that is an important factor for the formation of a person's behavior (Notoadmodjo, 2003). If a person's knowledge is as low as the knowledge of post partum blues then it can affect the occurrence of post partum blues. Another factor that affects post partum blues events is the type of labor. Childbirth with some medical technology (the use of obstetric devices such as caesarea, episiotomy) can trigger post partum blues. Caesarean section surgery is a medical intervention that may lead to unexpected emotional reactions, the emergence of negative views from neighbors due to normal delivery, surgical scars, feelings of being completely female, disrupted by daily activity due to surgical wounds.

Husband support factors also affect post partum blues events. Family especially husband has a very meaningful role for each member. These roles are among others as a driver (support) between family members in particular to help mothers perform tasks in role adaptation. In a new mother who has a baby (primipara) will feel the feelings of different, perhaps not even imagined before, in this condition the support of the husband is needed..

Demographic factors such as parity can also affect the occurrence of post partum blues. Low parity (parity one), unpreparedness of the mother facing the first delivery is a factor causing the incompetence of pregnant women in dealing with complications that occur during pregnancy, labor and postnatal. The lack of experience or even the birth of an unexpected child can lead to a mother's rejection of the child (Sulistyawati, 2009).

This study aims to analyze the factors of knowledge, type of childbirth, support of husband and parity and the most dominant factors that influence post partum blues on post partum mothers at Puskesmas Propo Pamekasan.

\section{METHODS}

The design of this study was cross sectional. This study was conducted on 25 January - 25 February 2018. The measured variables consisted of free variables of Knowledge, type of delivery, husband support, and parity. The dependent variable is post partum blues event. The sample consisted of 86 post partum mothers selected using simple random sampling technique. The instrument uses a questionnaire. Data analysis using logistic regression statistic test.

\section{RESULTS}

\section{Analisis Univariat}

Picture 1. Frequency Distribution Characteristics of respondent's age at Puskesmas Proppo Pamekasan $(\mathrm{n}=86)$

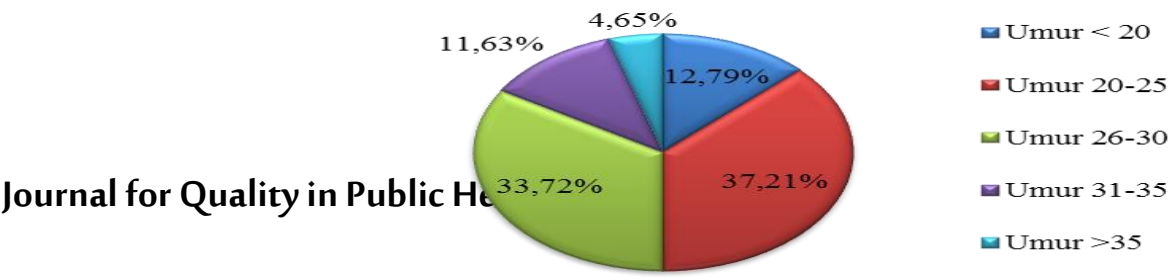


Based on the picture above, the age of respondents almost half (37.21\%) aged 20-25 years of 32 respondents.

Picture 2. Frequency Distribution of Respondent's Last Educational Characteristics at Puskesmas Proppo Pamekasan $(\mathrm{n}=86)$

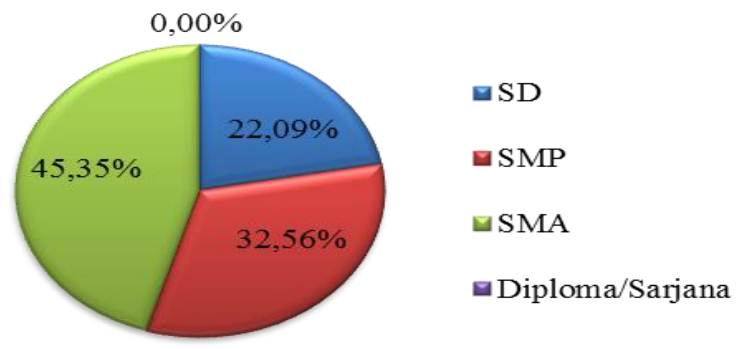

Based on the picture above, the last education of respondents almost half (45.35\%) high school education that is 39 respondents

Picture 3. Frequency Distribution of Respondent Job Characteristics at Puskesmas Proppo Pamekasan $(\mathrm{n}=86)$

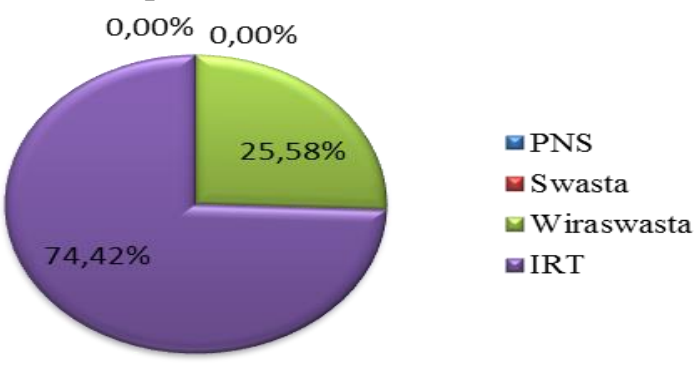

Based on the picture above, most respondents work (74.42\%) work as housewife that is 64 respondents.

Picture 4. Frequency Distribution of Respondents' Income Characteristics at Puskesmas Proppo Pamekasan $(\mathrm{n}=86)$

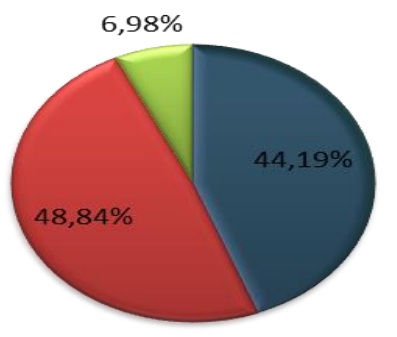

$\mathbf{a}<$ Rp. 500.000,-

- Rp. 500.000,- s/d Rp.

1.000.000,-

$\square>$ Rp. 1.000.000

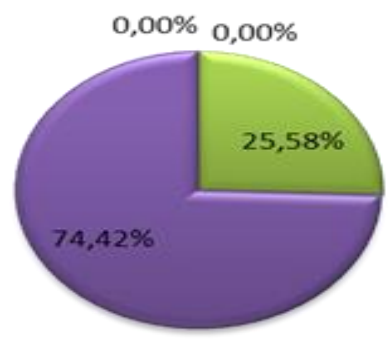

- PNS

- Swasta

Wiraswasta

aIRT 
Based on the picture above, the income of almost half (48.84\%) earns Rp 500,000 - 1.000.000 per month ie 42 respondents.

Table 1. Frequency Distribution Respondent's knowledge characteristic at Puskesmas Proppo Pamekasan $(\mathrm{n}=86)$

\begin{tabular}{cccc}
\hline No & Knowledge & Total & \% \\
\hline 1 & Good & 12 & 13,95 \\
\hline 2 & Middle & 60 & 69,77 \\
\hline 3 & Less & 14 & 16,28 \\
\hline & Total & $\mathbf{8 6}$ & $\mathbf{1 0 0}$ \\
\hline
\end{tabular}

From the above table, the majority of respondents (69.77\%) "Middle" are 60 respondents.

Table 2. Distribution of Respondents by Type of Labor at Puskesmas Proppo Pamekasan $(n=86)$

\begin{tabular}{cccc}
\hline No & Type of Labor & Total & \% \\
\hline 1 & Normal & 70 & 81,40 \\
\hline 2 & SC & 16 & 18,60 \\
\hline & Total & $\mathbf{8 6}$ & $\mathbf{1 0 0}$ \\
\hline
\end{tabular}

From the above table, the type of labor of respondents is almost entirely $(81.40 \%)$ "normal" by 70 respondents

Table 3. Distribution of respondents based on husband support at Puskesmas Proppo Pamekasan ( $\mathrm{n}=$ 86)

\begin{tabular}{cccc}
\hline No & Husband Support & Total & \% \\
\hline 1 & High & 17 & 19,77 \\
\hline 2 & Middle & 53 & 61,63 \\
\hline 3 & Low & 16 & 18,60 \\
\hline & Total & $\mathbf{8 6}$ & $\mathbf{1 0 0}$ \\
\hline
\end{tabular}

From the above table, the support of most of the respondent's husband $(61.63 \%)$ got husband support "Middle" that is 53 respondents.

Table 4. Distribution of Respondents by Parity at Puskesmas Proppo Pamekasan $(n=86)$

\begin{tabular}{clccc}
\hline No & & Paritas & Total & \% \\
\hline 1 & Primi & 48 & 55,81 \\
\hline 2 & Multi & 29 & 33,72 \\
\hline 3 & Grande & 9 & 10,47 \\
\hline Total & & $\mathbf{8 6}$ & $\mathbf{1 0 0}$ \\
\hline
\end{tabular}

From the above table, the majority of respondents (55.81\%) are primipara by 48 respondents.

Table 5. Distribution of respondents based on post partum blues events at Puskesmas Proppo Pamekasan $(\mathrm{n}=86)$

\begin{tabular}{cccc}
\hline No & Post Partum Blues Events & Total & \% \\
\hline 1 & Post partum Blues & 65 & 75,58 \\
\hline 2 & No post partum blues & 21 & 24,42 \\
\hline & Total & $\mathbf{8 6}$ & $\mathbf{1 0 0}$ \\
\hline
\end{tabular}


From the above table, the post partum blues of most respondents $(75.58 \%)$ experienced post partum blues of 65 respondents.

Bivariate Analysis

Table 6. Cross-tabulation Knowledge of Post Partum Blues at Puskesmas Proppo Pamekasan $(\mathrm{n}=86)$

\begin{tabular}{|c|c|c|c|c|c|c|}
\hline \multirow{2}{*}{ Knowledge } & \multicolumn{4}{|c|}{ Post Partum Blues } & \multirow{2}{*}{ Total } & \multirow{2}{*}{$\%$} \\
\hline & PPB & $\%$ & No PPB & $\%$ & & \\
\hline Good & 3 & 3,49 & 9 & 10,47 & 9 & 13,95 \\
\hline Middle & 49 & 56,98 & 11 & 12,79 & 11 & 69,77 \\
\hline Less & 13 & 15,12 & 1 & 1,16 & 1 & 16,28 \\
\hline Total & 65 & 75,59 & 21 & 24,42 & 21 & 100,0 \\
\hline
\end{tabular}

The result of bivariate analysis between knowledge factor and post partum blues occurrence is found that from 86 post partum mothers with enough knowledge, post partum blues were 49 respondents $(56,98 \%)$.

Table 7. Cross tabulation of type of labor on Post Partum Blues at Puskesmas Proppo Pamekasan (n $=86$ )

\begin{tabular}{|c|c|c|c|c|c|c|}
\hline \multirow{2}{*}{ type of labor } & \multicolumn{4}{|c|}{ Post Partum Blues } & \multirow{2}{*}{ Total } & \multirow{2}{*}{$\%$} \\
\hline & PPB & $\%$ & No PPB & $\%$ & & \\
\hline Normal & 52 & 60,46 & 18 & 20,93 & 70 & 81,40 \\
\hline $\mathrm{SC}$ & 13 & 15,12 & 3 & 3,49 & 16 & 18,60 \\
\hline Total & 65 & $\mathbf{7 5 , 5 8}$ & 21 & 24,42 & 86 & 100,0 \\
\hline
\end{tabular}

Result of analysis between type of delivery to post partum blues event, it is known that from 86 post partum mothers giving birth normally, post partum blues counted 52 respondents $(60,46 \%)$.

Table 8. Cross tabulation of Husband Support Against Post Partum Blues Event at Puskesmas Proppo Pamekasan $(n=86)$

\begin{tabular}{|c|c|c|c|c|c|c|}
\hline \multirow[b]{2}{*}{ Husband Support } & \multicolumn{4}{|c|}{ Post Partum Blues } & \multirow[b]{2}{*}{ Total } & \multirow[b]{2}{*}{$\%$} \\
\hline & PPB & $\%$ & $\begin{array}{c}\text { NO } \\
\text { PPB }\end{array}$ & $\%$ & & \\
\hline High & 6 & 6,98 & 11 & 12,79 & 17 & 19,77 \\
\hline Middle & 44 & 51,16 & 9 & 10,47 & 53 & 61,63 \\
\hline Low & 15 & 17,44 & 1 & 1,16 & 16 & 18,60 \\
\hline Total & 65 & 75,58 & 21 & 24,42 & 86 & 100,0 \\
\hline
\end{tabular}

The result of analysis between husband support factor and post partum blues occurrence showed that 86 post partum mothers who received husband support were having postural blues as many as 44 respondents $(51.16 \%)$. 
Table 9. Cross- Tabulation Parity Against Post Partum Blues Events at Puskesmas Proppo Pamekasan $(\mathrm{n}=86)$

\begin{tabular}{|c|c|c|c|c|c|c|}
\hline \multirow{2}{*}{ Paritas } & \multicolumn{4}{|c|}{ Post Partum Blues } & \multirow{2}{*}{ Total } & \multirow{2}{*}{$\%$} \\
\hline & PPB & $\%$ & No PPB & $\%$ & & \\
\hline Primipara & 37 & 43,02 & 11 & 12,79 & 48 & 55,81 \\
\hline Multipara & 22 & 25,58 & 7 & 8,14 & 29 & 33,72 \\
\hline Grande Multipara & 6 & 6,98 & 3 & 3,49 & 9 & 10,47 \\
\hline Total & 65 & $\mathbf{7 5 , 5 8}$ & 21 & 24,42 & 86 & 100,0 \\
\hline
\end{tabular}

Result of analysis between parity to post partum blues occurrence from 86 postpartum mothers obtained with primiparity parity, experiencing post partum blues counted 37 respondents $(43,02 \%)$.

\section{DISCUSSION}

\section{A. The Effect Of Knowledge On PPB at Puskesmas Proppo Kabupaten Pamekasan}

From the results of Logistic Regression analysis obtained $p$ value $=0.007$ means that there is influence of mother's knowledge on post partum blues event at Puskesmas Proppo Pamekasan District. OR $=8,149$ which means that if mother have less knowledge about post partum blues, hence have risk of post partum blues 8,149 times bigger than post partum mother having good knowledge.

This research is in accordance with the opinion of Notoatmodjo (2012) which states that knowledge is the result of knowing and occurs after doing the sensing of an object so that knowledge is an important factor for the formation of a person's behavior. Knowledge can be obtained either directly or indirectly and the knowledge gained will affect the development of one's behavior. Knowledge basically occurs from a number of facts and theories that enable a person to be able to solve the problem he faces, where knowledge is initiated from know, understand, application and able to decipher the material that has been studied.

Knowledge has an important role for post partum mothers in determining attitudes or actions. The better your knowledge about post partum blues, the better it will be in the post partum period. Level of education one of which affects knowledge, the higher the level of a person's education the better his knowledge, especially knowledge of post partum blues. The level of education is very influential on emotional intelligence, mothers who have higher education will have a more rational way of thinking, and the easier to receive information. Mothers who do not get adequate information about pregnancy and childbirth will generally find it difficult to adapt to their new roles and activities to allow for psychological disorders such as post partum blues. This is because the role change in a woman becomes a mother who is not ready when facing birth. The demands of the mother's role in taking care of the family, especially the children and the household, make the mother must adjust to face new role and activity as a mother especially in the first weeks or month after giving birth.

\section{B. Effect Of Type Of Delivery To PPB at Puskesmas Proppo Kabupaten Pamekasan.}

From the analysis of Logistic Regression test, there is a Sign value of 0.485 which means that there is no influence of postpartum maternal type on post partum blues incidence in Puskesmas Proppo Pamekasan District. OR $=1,822$, it means that if post partum mother gave birth with normal delivery type, then post partum mother did not experience post partum blues 1,822 times bigger compared to post partum mother giving birth with SC type of labor.

One of the factors that influences the type of labor is the age of the mother. Nearly half of respondents aged 20-25 years of childbirth as normal as 27 respondents $(31.40 \%)$. The age is the ideal age for pregnancy and childbirth as it reduces the risk of health problems during pregnancy and childbirth. In addition, when viewed from the development of maturity, women in this age group has a maturity of reproduction, emotional and social aspects. In addition, the age is the right age to give birth normally if the mother does not have an indication SC. This is because at that age the mother's 
body is primed enough to give birth normally. At this age the mother has the power (power) is good enough to push and push the fetus. Pelvic cavity as the baby's birth canal has grown more maturely so that it can be passed by a baby's head whose normal size is between $9-10 \mathrm{~cm}$ in diameter. As well as reproductive organs such as uterus and vagina are also already strong to support childbirth. According Manuaba (2012) the most important factor in the process of labor is the power of the power of the mother as well as uterine contractions.

There are several factors that cause it to happen to the mother of post partum such as the duration of labor and problems in the baby. a prolonged labor will make the mother have a less than satisfactory labor experience. The duration of labor will make the mother have an unsatisfactory labor experience, so the mother exhibits a negative self-image and may continue to be an anger that may complicate the process of maternal adaptation to her new role and function.

In addition to the old factor of labor, the problems experienced by the baby also causes the mother to have post partum blues, because it causes the mother to lose interest to take care of her baby. Problems in these infants include birth or birth complications with sex not in accordance with expectations, or birth with congenital defects. Infant health conditions will also be an additional stressor for the mother, babies become need more attention, care and cost.

\section{The Effect Of Husband Support on PPB at Puskesmas Proppo Kabupaten Pamekasan}

From the results of data analysis Regesi Logistic Sign Value 0.005 means there is influence of husband support to post partum blues events at Puskesmas Proppo Pamekasan District. OR $=4,518$, implies that if the post partum mother has low husbands support, the risk of having post partum blues is 4.518 times greater than mothers who have high husbands support.

The husband is the wife's spouse (father of the children), the husband has a full responsibility in a family and the husband has an important role, where the husband is demanded not only as a breadwinner but the husband as a motivator in various policies that will in deciding including family planning (Chaniago, 2010).

Husband support for post partum mother is needed so that mother can go through post partum period comfortably and to avoid post partum blues. Because the husband is the closest person to the mother in the family. Husband support is the biggest factor to trigger the Postpartum Blues. This is because the support of the husband is an important coping strategy when experiencing stress and serves as a preventive strategy to reduce stress. The role of husband in minimizing postpartum blues is to understand the needs of the wife, husband accompanying the wife in the care of the baby, the husband do the household tasks are usually done wife, the obligation of the husband to share the attention to the baby and mother. Although the presence of the baby is very pleasant and happy, it should be remembered that the mother who gave birth to physical touch in the post-birth period With the social support of a good husband then the mother does not happen postpartum blues.

\section{The Effect Of Parity on PPB at Puskesmas Proppo Kabupaten Pamekasan}

From the results of analysis using Logistic Regression obtained Sign value 0.749 means that there is no influence of post partum mother parity on post partum blues events at Puskesmas Proppo Pamekasan District. OR $=1,153$. This implies that if the post partum mother of multiparous grande parity, then the post partum mother did not experience post partum blues 1.153 times greater than the postpartum mother with primiparity parity.

Age factor affects mother's parity. The result of research got most respondent of primipara parity counted 48 responden $(55,81 \%)$. Parity with primipara in the respondents is almost half aged 20-25 years. Where age is a safe age for pregnancy and childbirth because the reproductive organs are ripe. This is consistent with Ekasari's statement that the age at which pregnancy affects the mother's readiness so that the quality of human resources is increasing and the readiness to nourish the next generation can be guaranteed.

The number of children produced has an influence on postpartum blues events, labor, length of labor and complications experienced after delivery, especially in primiparous moms can affect the psychological mother, where the greater the physical trauma experienced the greater the psychic trauma that appears, and this the more heavily felt in women who first gave birth to their child. This is 
in line with research conducted by Paykel and Inwood (Regina, et al, 2006) says that the post partum blues are mostly found in primiparous women given that the role of a mother and everything related to her baby is a completely new situation for her and can cause stress.

Pregnancy is traditionally viewed as an emotional crisis by some psychologists. Conditions experienced by women in the first experience of pregnancy is a new condition faced so that not infrequently cause stress for him. Some women mention pregnancy with a feeling of happiness but do not rule out anxiety arise.

For that it takes a good self-preparation starting from the time of pregnancy in order to avoid post partum blues on postpartum mothers, such as self preparation during pregnancy is necessary so that the birth has a good confidence so as to reduce the risk of post partum blues. Class of pregnant women in this case is very instrumental because with active mothers come to the class of pregnant women who become the mandatory agenda of the local health center can consult directly to health workers about pregnancy and preparation of childbirth and post partum. with a special class for pregnant mothers, mother-to-child knowledge of pregnancy and preparation during pregnancy will surely increase. That way, will prevent the occurrence of things - things that are not in want during pregnancy until the birth process takes place. That way, mothers who attend this pregnancy class can avoid the risk of post partum blues attack during post partum, which will be dangerous for the child or mother.

\section{E. The Most Dominant Factor Affecting PPB at Puskesmas Proppo Kabupaten Pamekasan.}

Based on statistical test of logistic regression obtained value on knowledge factor $p=0,007$; OR 8.149 and on husband support $\mathrm{p}=0.005$; OR $=4,518$. This implies that the knowledge and support of the husband has the most dominant influence of other factors.

Post partum blues is a form of mild symptoms or temporary depression with a duration of 3-7 days postpartum. Where postpartum blues symptoms usually occur on the third or fourth postpartum day and peak on the fifth or seventh to fourteen post-partum days. However, if not handled properly will develop into a more severe condition. This can be characterized by feelings of irritability, sadness, loneliness or rejection, anxiety, confusion, anxiety, fatigue, forgetfulness, tend to cry easily, annoyance, feelings of despair even to the mother feel reluctant to take care of her own baby.

The most dominant factor in post partum blues events is dependent on the support of the husband. Husband support is the biggest factor to trigger the Postpartum Blues. Husband's support is taking time out for mothers if the mother is tired with her routine, intimate communication and intimate relationships, the most significant factor being the trigger for postpartum blues.

For that support is needed and very important husband by post partum mothers. Because such support can build a positive atmosphere. Support is in the form of helping the wife in the care of the baby for example when the mother breastfeed her baby, the father also helped maintain. Father can accompany mother and baby, lift baby out of bed, change baby's diaper, give baby to mother during nursing hour, and return baby to bed when baby has fallen asleep again.

\section{CONCLUSION}

1. There is a influence of knowledge on post partum blues occurrence in post partum mothers at Pamekasan Public Health Center ( $\mathrm{p}=0,007$; OR = 8,149).

2. There is no influence of the type of labor on post partum blues occurrence in post partum mother at Puskesmas Proppo Pamekasan ( $\mathrm{p}=0,485 ; \mathrm{OR}=1,822)$.

3. There is influence of husband support to post partum blues occurrence on post partum mother at Puskesmas Proppo Pamekasan ( $\mathrm{p}=0,005 ; \mathrm{OR}=4,518$ ).

4. There is no parity effect on post partum blues occurrence in post partum mothers at Puskesmas Proppo Pamekasan $(\mathrm{p}=0,749$; OR $=1,153)$.

5. The most dominant factor affecting post partum blues incidence in post partum mothers in Pamekasan Proppo Puskesmas is husband support $(\mathrm{p}=0,005$; OR $=4,518)$. 
It is necessary to do research to know the factor analysis of post partum blues occurrence in post partum mother with different variable that is baby condition in the form of baby's gender and also baby's health condition. Need to improve counseling on post partum and family mothers in facing post partum to avoid post partum blues events. Health education can be given when pregnant women accompanied by the husband to do ANC (Ante Natal Care) to the midwife. Health education is about post partum, newborn care, and role change in post partum.

\section{REFERENCES}

Agusti, \& Pertiwi. (2015). Pengaruh Kompetensi, Independensi dan Profesionalisme terhadap Kualitas Audit (Studi Empiris pada Kantor Akuntan Publik Se Sumatera). Jurnal Ekonomi. Volume 21 Nomer 3.

Agustina, R. \& Sulaiman. (2013). Hubungan Motivasi dan Kepuasan Kerja dengan Kinerja Guru pada SMA Negeri di Kabupaten Pidie. Sains Riset Volume 3- no 1. Hlm 1-10.

Ambarwati, E. (2009). Asuhan Kebidanan Nifas. Yogjakarta: Mitra Cendikia.

Anggraini, Y. (2010). Asuhan Kebidanan Masa Nifas. Yogyakarta: Pustaka Rihama.

Suharsimi, A. (2006). Prosedur Penelitian : Suatu Pendekatan Praktek Edisi Revisi. Jakarta: PT. Rineka Cipta.

Diah Damayanti, A. \& Santi, M. (2017). the influence of the integrated antenatal with postpartum blues on postpartum mother. $1-6$.

Ayu, F. R., \& Lailatushifah, S. N. (2008). Dukungan Suami dan Depresi Pasca Melahirkan. Jurnal Psikologi Universitas Mercu Buana Yogyakarta.

Bobak. (2005). Buku Ajar Keperawatan Maternitas Edisi 5. Jakarta: EGC.

Buduarto, E. (2016). Metodologi Penelitian Kedokteran Sebuah Pengantar. Jakarta: EGC.

Bydlowski, S. (2016). Dvelopment of the child in its fourth years: Which link with the postpartum blues? 1 -6.

Cahyo, K., Rimawati, E., Widagdo, L., \& Solikha, D. A. (2008). Kajian Adaptasi Sosial Psikologis Pada Ibu Setelah Melahirkan (Post Partum) Di Ruang Rawat Inap RSUD Kota Semarang. Jurnal Promosi Kesehatan Indonesia.Vol.3. No 1.

Chaniago. (2002). Kamus Lengkap Bahasa Indonesia. Bandung: Pustaka Setia.

Daeli, V. (2012). Hubungan Sumber Informasi Dan Dukungan Keluarga Dengan Pengetahuan Ibu Tentang Postpartum Blues Pada Masa Nifas Di Puskesmas Ujong Patihah Kecamatan Kuala Kabupaten Nagan Raya. Skripsi. Diploma IV Kebidanan (STIKes) U’Budiyah Banda Aceh. Diperoleh tanggal 21 Maret 2015 dari http://www.daa.uui.ac.id.

Dep Kes RI. (2008). Asuhan Kebidanan Persalinan dan Kelahiran. Jakarta: EGC. Jakarta: JHPIEGO dan POGI.

Arneliwati, D. M. (2015). Faktor - Faktor Yang Mempengaruhi Post Partum Blues di RSUD Arifin Achmad dan Rumah Sakit Petala Pekanbaru.Vol 2 No 2.

Dharma Kelana Kusuma. (2011). Metodologi Penelitian Keperawatan (Pedoman Melaksanakan Dan Menerapkan Hasil Penelitian). Jakarta Timur: CV. Trans Info Media.

Devi, K. (2015). Hubungan Antara Karakteristik Ibu, Kondisi Bayi dan dukungan Sosial Suami Dengan Post Partum Blues Pada Ibu Dengan Persalinan SC di Rumah Sakit Umum Ahmad Yani Metro. Vol 9. No3. Hal 115125.

Elvira, S. (2006). Depresi Pasca Persalinan. Jakarta: Balai Penerbit FKUI. 
Fatimah, S. (2009). Hubungan Dukungan Suami dengan Kejadian Postpartum Blues pada Ibu Primipara di Ruang Bugenvile RSUD Tugurejo Semarang. Artikel Riset Keperawatan.

Sulistiyowati, F. R. (2016). Gambaran ibu postpartum dengan baby bluesdi Rumah Sakit Permata Bunda Purwodadi. 15-20.

Gale, S. \& Harlow, B. L. (2007). Postpartum Mood Disorders: a review of clinical and epidemological factors. Journal of Psychosomatic Obstetrics and Gynecolog.

Gaynes BN, Lohr KN, Meltzer-Brody S, Gartlehner G., \& Swinson T. Perinatal depression: a systematic review of prevalence and incidence.

Harymawan. (2007). Dukungan Suami dan Keluarga. http://www.infowikipedia.com. Diakses pada tanggal 06 April 2018.

Ibrahim, F., Rahma, \& Ikhsan, M. (2012). Faktor-Faktor yang Berhubungan dengan Depresi Postpartum di RSIA Pertiwi Makasar. Jurnal.

Chasanah, I. N., Pratiwi. K., \& Sri Martuti. (2017). Postpartum Blues Pada Persalinan di bawah Usia Dua Puluh Tahun. $117-123$.

Intan, K. (2015). Panduan Praktek Laboratorium dan Klinik Perawatan Antenatal, Intranatal, Postnatal, Bayi baru lahir dan kontrasepsi. Jakarta: Salemba Medika.

Pratiwi, K., Chasanah, I. N., \& Martuti, S. (2017). Postpartum Blues Pada Persalinan Dibawah Usia Dua Puluh Tahun. Jurnal Psikologi: DOI: https://doi.org/10.14710/jpu.15.2.117-123.

Kurniawan. (2012). Gambaran Tingkat Pengetahuan Pasien TB. Paru. Rencana Pulang Tentang Penyakit TB.Paru di Ruang Rawat Inap. RS.Paru Dr. M. Goenawan Partowidiga. http://www.lib.ui.ac.id.pdf.

Latifah, L., \& Hartati. (2007). Efektifitas Skala Endinburgh dan Skala Beck dalam Mendeteksi Risiko Depresi Postpartum di RSU Prof. DR. Margono Soekarjo Purwokerto. Jurnal Keperawatan Soedirman (The Soedirman Juenal Nursing), Vol 1, No 1: 15-19.

Latipun. (2008). Psikologi Konseling. Malang: Universitas Muhammadiyah Malang.

Leveno, K. J., Cunningham, F. G., Gant, N. F., Alexander, J. M., Bloom, S. L., Casey, B. M., et al. (2009). Williams Manual of Obstetrics. In U. Brahm, Obstetri Williams Panduan Ringkas. Jakarta: EGC.

Machmudah. (2010). Pengaruh Persalinan dengan Komplikasi Terhadap Kemungkinan Terjadinya PospartumBlues di Kota Semarang. Tesis Keperawatan Universitas Indonesia.

Mansur A.M., Rezaul K. M., \& Mahmudul H. M. (2014). quality of antenatal care in primary health care centers of Bangladesh.

Manuaba. (2013). Ilmu Kebidanan Penyakit Kandungan dan Keluarga Berencana,edisi 3, Jakarta: Buku Kedokteran ECG.

Manurung, S., Lestari, T. R., Suryati, B., Mitadwiyana, B., Karma, A., \& Paulina, K. (2011). Efektivitas Terapi Musik Terhadap Pencegahan Postpartum Blues pada Ibu Primipara di Ruang kebidanan RSUP Cipto Mangunkusumo Jakarta Pusat. Jurnal Buletin Penelitian Sistem Kesehatan. Vol.4 No.1.hlm 17-23.

Marmi. (2012). Asuhan Neonatus, Bayi, Balita dan Anak Prasekolah. Yogyakarta: Pustaka Pelajar.

Akbarzadeh, M., Mokhtaryan, T., Amooee, S., Moshfeghy, Z., \& Zare, N. (2015). Investigation of the effect of religious doctrines on religious knowledge and attitude and postpartum blues in primiparous women. 570 - 576 .

Ismail, N.B., \& Hamzah, S. H. (2017). Pendekatan Tazkiyah Al - Nafs dalam menghadapai postpartum depression : satu analisis literatur. $132-138$. 
Hidayah, N., Dwi Rahmawati, J. E., \& Azizah, N. (2016). Support Sistem, Pengalaman Persalinan Dengan Resiko Post Partum Blues Di Bpm Yayuk Kalbariyanto Kudus. 44 - 52.

Notoatmojo. (2010). Metodologi Penelitian Kesehatan. Jakarta: Rieka Cipta.

Nursalam. (2013, 2016). Metodologi Penelitian Ilmu Keperawatan, edisi 3 dan 4, Jakarta: Salemba Medika.

Nursalam. (2008). Konsep dan Penerapan Metodologi Penelitian Ilmu Keperawatan: Pedoman Skripsi, Tesis, dan Intrumen. edisi 2, Jakarta: Salemba Medika.

Pearlstein T. (2009). Postpartum depresion. Am J Bet. Obstet Gynecol.

Kusuma, P. D. (2017). Karakteristik penyebab terjadinya depresi postpartum pada primipara dan multipara. 36 45 .

Puskesmas Proppo. (2017). Buku Laporan Puskesmas tahun 2016. Pamekasan. Puskesmas Proppo.

Rahmandani, A., Karyono, \& Dewi, E. K. (2008). Strategi Penanggulangan Coping pada Ibu yang Mengalami Postpartum Blues di RSU Daerah Kota Semarang. Journal Psikologi.

Rusli, R. A., Meiyuntariningsih, T., \& Warni, W. E. (2011). Perbedaan Depresi Pasca Melahirkan pada Ibu Primipara Ditinjau dari Usia Ibu Hamil. Jurnal INSAN. Vol 13, No 01: 21-31

Setiadi. (2008). Konsep \& keperawatan keluarga. Yogyakarta: Graha ilmu.

Soep. (2009). Pengaruh Intervensi Psikoedukasi Dalam Mengatasi Depresi Postpartum di RSU Dr. Pirngadi Medan. Tesis keperawatan Universitas Sumatra Utara.

Suherni dkk. (2013). Perawatan Masa Nifas. Jogjakarta: Fitramaya.

Suhita, Byba Melda. (2017). Metodologi Penelitian Kesehatan. Ponorogo: Forum Ilmiah Kesehatan (FORIKES).

Varney, H. (2008). Buku Saku Bidan, Jakarta: EGC.

Dwi, W., Wijayanti K., \& Ngadiyono. (2017). Pengaruh Pemberian KIE (Komunikasi Informasi Edukasi) Persiapan Persalinan Dan Nifas Terhadap Kejadian Postpartum Blues.Vol 6, No 14 dan Hal. 1-8.

Takahachi, Y., RN, NM, PHN, PhD. \& Tamakoshi, K., MD, PhD. (2014). Factors associated with early postpartum maternity blues and depression tendency among japanese mothers with full-term healthy infants. $129-138$.

Yulianti. (2012). Faktor-Faktor yang Berhubungan dengan Post Partum Blues pada Ibu Pasca Persalinan di Wilayah Kerja Puskesmas Kajhu Kecamatan Baitussalam Kabupaten Aceh Besar. Skripsi. Diploma IV Kebidanan (STIKes) U'Budiyah Banda Aceh. Diperoleh tanggal 8 April 2015 dari http://www.daa.uui.ac.id. 